Louisiana State University

LSU Digital Commons

$1-1-2013$

\title{
Particulate Matter Containing Environmentally Persistent Free Radicals and Adverse Infant Respiratory Health Effects: A Review
}

Jordy Saravia

LSU Health Sciences Center - New Orleans

Greg I. Lee

LSU Health Sciences Center - New Orleans

Slawo Lomnicki

Louisiana State University

Barry Dellinger

Louisiana State University

Stephania A. Cormier

LSU Health Sciences Center - New Orleans

Follow this and additional works at: https://digitalcommons.Isu.edu/biosci_pubs

\section{Recommended Citation}

Saravia, J., Lee, G., Lomnicki, S., Dellinger, B., \& Cormier, S. (2013). Particulate Matter Containing Environmentally Persistent Free Radicals and Adverse Infant Respiratory Health Effects: A Review. Journal of Biochemical and Molecular Toxicology, 27 (1), 56-68. https://doi.org/10.1002/jbt.21465

This Article is brought to you for free and open access by the Department of Biological Sciences at LSU Digital Commons. It has been accepted for inclusion in Faculty Publications by an authorized administrator of LSU Digital Commons. For more information, please contact ir@lsu.edu. 


\title{
Particulate Matter Containing Environmentally Persistent Free Radicals and Adverse Infant Respiratory Health Effects: A Review
}

\author{
Jordy Saravia ${ }^{1}$, Greg I. Lee ${ }^{1}$, Slawo Lomnicki ${ }^{2}$, Barry Dellinger ${ }^{2}$, and Stephania A. Cormier ${ }^{1}$ \\ ${ }^{1}$ Department of Pharmacology and Experimental Therapeutics, Louisiana State University Health \\ Sciences Center, New Orleans, LA 70112, USA \\ ${ }^{2}$ Department of Chemistry, Louisiana State University, Baton Rouge, LA 70803, USA
}

\begin{abstract}
The health impacts of airborne particulate matter (PM) are of global concern, and the direct implications to the development/exacerbation of lung disease are immediately obvious. Most studies to date have sought to understand mechanisms associated with PM exposure in adults/adult animal models; however, infants are also at significant risk for exposure. Infants are affected differently than adults due to drastic immaturities, both physiologically and immunologically, and it is becoming apparent that they represent a critically understudied population. Highlighting our work funded by the ONES award, in this review we argue the understated importance of utilizing infant models to truly understand the etiology of PM-induced predisposition to severe, persistent lung disease. We also touch upon various mechanisms of PM-mediated respiratory damage, with a focus on the emerging importance of environmentally persistent free radicals (EPFRs) ubiquitously present in combustion-derived PM. In conclusion, we briefly comment on strengths/ challenges facing current PM research, while giving perspective on how we may address these challenges in the future.
\end{abstract}

\section{Keywords}

Particulate Matter; Environmentally Persistent Free Radicals; Infant; Respiratory Health; Immunomodulation

\section{PARTICULATE POLLUTION}

Airborne particulate matter (PM) is generated by a variety of sources including vehicular exhaust, flaring of hydrocarbons at refineries, coal burning at power plants, and thermal treatments of hazardous wastes. PM is often categorized according to mean aerodynamic diameter with sizes ranging from coarse particles $(2.5-10 \mu \mathrm{m}$ in diameter) to the smaller fine $(<2.5 \mu \mathrm{m})$ and ultrafine $(<0.1 \mu \mathrm{m})$ particles. The smaller classes of PM are more apt to cause respiratory toxicity and dysfunction due to their propensity to deposit deep in the lower airways and alveoli [1]. Owing to the increasing knowledge of the detrimental health consequences of exposure to PM, the United States Environmental Protection Agency (US EPA) through the Clean Air Act has set National Ambient Air Quality Standards (NAAQS). The current recommendations for $\mathrm{PM}_{2.5}$ and $\mathrm{PM}_{10}$ are 35 and $150 \mu \mathrm{g} / \mathrm{m}^{3}$ within a 24-h

\section{(C) 2012 Wiley Periodicals, Inc.}

Correspondence to: Stephania A Cormier. scorm1@lsuhsc.edu.

Jordy Saravia and Greg I. Lee contributed equally. 
period, respectively, whereas the annual limit of exposure for $\mathrm{PM}_{2.5}$ is $15 \mu \mathrm{g} / \mathrm{m}^{3}$ [2]. The World Health Organization (WHO) is more stringent with daily exposure limits for $\mathrm{PM}_{2.5}$ and $\mathrm{PM}_{10}$ with concentrations set at less than 25 and $50 \mu \mathrm{g} / \mathrm{m}^{3}$, respectively; and an annual $\mathrm{PM}_{2.5}$ limit at less than $10 \mu \mathrm{g} / \mathrm{m}^{3}[3,4]$. There are no current recommendations for daily or annual exposure limits for ultrafine particles either nationally or globally. Astoundingly, the WHO estimates that if air quality guidelines were met, an estimated 1.09 million premature deaths would have been prevented in 2008 [5,6].

Although extensive research has focused on outdoor air pollution, indoor air pollution (IAP) also poses a significant health risk. Most IAP is a mixture of cigarette smoke and/or biomass combustion from cooking stoves - the products of which contain similar organic species as found in outdoor air pollution. Those with the greatest risk from exposure to IAP are, as expected, those who are exposed for the longest period of time (i.e., women, infants, young children, and the elderly) and/or those with underlying immune/pulmonary/cardiovascular disorders. Worldwide, exposure to IAP contributes to nearly two million premature deaths annually due to acute lower respiratory tract infections in children under five, chronic obstructive pulmonary disease in adults (equivalent to a lifetime of cigarette smoking), and respiratory tract cancers in adults $[7,8]$. There are additional known and suspected health risks associated with exposure to IAP such as low birth weight, anemia, stunted growth in infants and children $[9,10]$, interstitial lung disease, increased incidence of tuberculosis [11], cardiovascular disease [12,13], and cataracts [14,15]. IAP is thought to have such an impact on public health that the U.S. government has committed more than $\$ 50$ million to alleviate its negative consequences through the Global Partnerships Initiative and contributions to NIH's ongoing research funds [7]. This article briefly reviews the health effects associated with combustion generated PM in infants focusing on the respiratory effects and proposes a new mechanism for their role in respiratory disease.

\section{ENVIRONMENTALLY PERSISTENT FREE RADICALS: RESPONSIBLE FOR THE HEALTH IMPACTS OF PM?}

It has been demonstrated that size, shape, and composition of PM are important factors in determining toxicity $[16,17]$. In addition, organic pollutants are often associated with PM [18]. It was originally presumed that organic pollutants must be weakly associated (i.e., Van der Waals, hydrogen bonds) with PM; however, studies have demonstrated that organic pollutants can be surface-bound to PM and stubbornly resistant to removal, implying a much stronger chemical bond [19]. Indeed, several pioneering studies by our colleagues demonstrated that particular aromatic hydrocarbons chemisorb to the surface of PM through transition metal oxides [20-23]. This environmental phenomenon results in the production of a surface-stabilized free radical species. These radical species are very weakly reactive with $\mathrm{O}_{2}$ giving the ability to persist in ambient air for extended periods of time (hoursmonths) and at least $12 \mathrm{~h}$ in biological fluids (Figure 1). The stability of the radical is partly due to stabilization on the surface of the particle, whereas the persistency in biological systems is at least partially a result of a cyclic mechanism involving the biological regeneration of reactive oxygen species (ROS) [24]. These environmentally persistent free radicals (EPFRs) chemisorbed to PM are mostly semiquinone-type radicals similar to those found in cigarette smoke [25], but we have also identified them associated with PM from almost all combustion sources. Furthermore, there have been a number of studies concerning radicals associated with environmental PM [26-29]. Large quantities of similar semiquinone radicals have been found in PM collected from cities [22], with average radical concentrations being $\sim 10 \times$ higher for industrialized, highly populated locations than less densely populated areas (unpublished observations). Radical concentrations in these environmental samples, measured in spins/gram, were typically $2-10 \times$ higher than in cigarette tar [30,31], and each sample exhibited an electron paramagnetic resonance (EPR) 
spectrum with a $g$ value of $\sim 2.0033-2.004$, which is typical of oxygen-centered or oxygencontaining EPFRs. Owing to the recent discoveries of EPFRs, understanding of their impact on health is in its infancy. Their radical and regenerative nature, however, suggests the potential for causing dire health consequences, highlighting why further investigation is of grave importance. We have been working to understand the mechanism of toxicity and biological activity of EPFR-containing particles using in vitro and in vivo approaches; and thus, it is the focus of this review even though we appreciate the chemical complexity of PM and its many components (e.g., organics, particulates) that have also been shown to contribute to damaging health effects.

\section{INFANTS: A SPECIAL POPULATION AT RISK}

\section{PM and Feto-Infant Growth and Morbidity}

Epidemiological data support a link between elevations in PM and exacerbation of respiratory disease in adults $[32,33]$, and it is now widely accepted that exposure to PM contributes to inflammatory airways diseases, such as asthma [34]. More recently, investigators have begun to examine the effects of air pollution on infant/child health. Although the majority of these studies are epidemiological and typically related to tobacco smoke, they demonstrate a significant association between exposure to PM and feto-infant morbidity outcomes such as low birth weight and preterm birth [35, 36]. One inhalation study done in healthy humans concluded that particle deposition rate, when normalized to surface area of the lung, was 35\% higher in children compared to both adolescents and adults [37]. Additional concerns, however, include increased incidence of placental abruption in women exposed to PM levels that were well below EPA limits $\left(\mathrm{PM}_{2.5}>10.97\right.$ $\mu \mathrm{g} / \mathrm{m}^{3}$ and $\mathrm{PM}_{10}>25.04 \mu \mathrm{g} / \mathrm{m}^{3}$ ) compared to those not exposed to those levels of PM [35]. Racial/ethnic disparities in the effects of PM on feto-infant morbidity outcomes were also observed with African American infants being most at risk, suggesting that other factors such as social economic status, education, or even surrounding environment may also be an important confounding factor. A study in Korea suggested that area level social economic status modified the effects of PM on preterm births [38], where those who resided in low income areas had a higher probability of having a preterm birth when PM levels increased by $10 \mu \mathrm{g} / \mathrm{m}^{3}$, specifically if these elevated exposures occurred in the second trimester. More alarmingly, risk of respiratory death more than doubles for infants between the age of 7-12 months if exposure to elevated levels of PM occurred during the previous 6 months prior to death [39].

\section{PM and Asthma}

Since PM affects the growth and development of the embryo/fetus, it is not surprising that infants represent a particularly susceptible population to the effects of PM as they take in more air per body weight, their lungs are still developing (i.e., at birth only $6.7-17.5 \%$ of the alveoli are formed [40]), and they have immature immune systems. One of the main risk factors for adult asthma is early life insults to the lung (both structurally and immunologically) brought upon by environmental exposures [41]. Because of this, there has been a surge in the number of studies attempting to understand the role of environmental factors (i.e., particulate pollution or respiratory tract viral infections) in determining risk to develop asthma/wheeze and other child respiratory health concerns (Figure 2A). Unfortunately, still very few studies explore the interplay between all three factors (Figure 2B).

A large amount of epidemiological data exist linking elevated levels of PM and rate of hospitalization for children with adverse pulmonary events such as asthma exacerbations [42-46]. Indeed, several studies have demonstrated a positive correlation between PM 
exposure and lung function changes in children including decreases in forced vital capacity (FVC), forced expiratory flow (FEF), and forced expiratory volume $\left(\mathrm{FEV}_{1}\right)$ [47-50]. Furthermore, it has been shown that exposure to fine and ultrafine PM affects lung development, resulting in functional deficits in the adult [51,52]. To further support the link between early life exposure to PM and its effect on subsequent adult respiratory health, histopathological lung changes such as septal enlargement, fibrosis, glandular hyperplasia, and goblet cell metaplasia have been observed in autopsies of children less than 5 years of age that had been exposed to biomass fuel [53]. In the majority of these children, these data were consistent with pulmonary changes reminiscent of bronchitis.

\section{PM and Viral Infection}

A few epidemiological studies have associated risk for and severity of respiratory tract viral infection with living near a source of traffic pollution, observing that infants who lived closer to highways had an elevated risk of being hospitalized for severe influenza or respiratory syncytial virus (RSV)-induced bronchiolitis [54, 55]. Moreover, elevated levels of PM have been attributed to increased risk of postnatal mortality from respiratory tract viral infections [56, 57]. Currently, the RESPIRE study is the only randomized, controlled trial that has documented the benefits of reducing IAP on child pneumonia [58]. Data from this study suggest that up to $90 \%$ of exposure reductions are required to attain significant decreases in pneumonia risk and even a $22 \%$ risk reduction requires a $50 \%$ decrease in exposure [59], highlighting the dramatic impact of PM on child health. Similar data are obtained when looking specifically at exposure to diesel exhaust particles (i.e., increased susceptibility, viral burden, and disease severity to respiratory viral infections including influenza and RSV) [60-63].

Not only is there a clear association between increased ambient PM and hospitalization of childhood bronchiolitis and respiratory disease, but it has also been demonstrated that there is a corresponding increase in the amount of healthcare dollars spent annually [64]. Increases in healthcare cost are attributable to the increase in the amount of cases and the enhanced severity of bronchiolitis due to increased PM exposure. In fact, it is estimated that reducing levels of PM to just 7\% below the current annual standard would save the U.S. approximately $\$ 15$ million annually in healthcare costs [64], giving us not only a medical but an economic impetus to reduce combustion-derived PM emissions while also encouraging further investigations on how PM enhances infectious disease severity.

Limited mechanistic research that does exist for infants/children demonstrate that exposure to combustion-derived PM increases susceptibility to respiratory tract viral infections by dampening the initial immunological response while skewing the pulmonary immune response toward a T helper type 2 cell (Th2) response [65] — a response often seen in allergy with corresponding antibody production that is predominantly immunoglobulin type $\mathrm{E}$ ( $\operatorname{IgE}$ ), followed by an augmentation of downstream morbidities [66-69]. Altogether, these data suggest that EPFR-containing PM (i.e., roadway PM and diesel exhaust particles) (1) may be responsible for the increased risk for respiratory viral susceptibility and enhanced disease and (2) has a significant impact on the developing respiratory tract. Hence, the role of exposure to this class of PM on infantile susceptibility to viral infection is an area that requires much more attention. Much of the current data are derived primarily through epidemiological studies in which associations between PM and enhanced susceptibility to viral infections are suggested. Unfortunately, studies that further delve into the underlying mechanism of this phenomenon in an age appropriate animal model are severely limited. 


\section{Use of an Age-Relevant Model Is Critical}

Collectively, the aforementioned observations suggest that there are sensitive life stages during which exposure to elevated PM has particularly devastating and long-term effects. Furthermore, the different toxicokinetic and toxicodynamic properties due to age makes studying an age-relevant model to understand the mechanistic basis for enhanced respiratory morbidity and mortality crucial.

In age-relevant rodent models, we have observed specific adverse pulmonary effects including airway hyperresponsiveness, airway remodeling, lung inflammation characterized by influx of neutrophils in bronchoalveolar lavage fluid (BALF), peribronchial associated lymphoid tissue, and increased smooth muscle mass following acute (7-day) EPFR inhalation exposure [70]. These characteristics correspond to noneosinophilic, severe asthma in humans. Even more strikingly, we observe lung function deficits that persist into early adulthood (Figure 3) [70], which recapitulates what is seen in humans [71]. In comparison, adult rodents acutely exposed to combustion-generated ultrafine particles do not exhibit persistent changes in airway function, reinforcing the need to study these effects in an age appropriate model.

Clearly, it is important to consider the developmental status of the lung in models used to study the effects of PM and how interruption/deviation from normal maturation could be responsible for much of the long-term effects observed in humans. Although relatively little is known about the mechanism involved in PM-induced airways dysfunction, our data suggest that airway remodeling plays a major role in long-term dysfunction [70,72].

\section{MECHANISMS INVOLVED}

\section{Oxidative Stress}

There are many observed and hypothesized mechanisms to explain PM-induced respiratory effects. One of the most popular involves PM-driven oxidative stress [73-78]. Oxidative stress results from an impaired ability of antioxidants to protect from harmful ROS. Some of these include superoxide $\left(\mathrm{O}_{2}{ }^{-}\right)$, hydroxyl radical $\left(\mathrm{HO}^{*}\right)$, and hydrogen peroxide $\left(\mathrm{H}_{2} \mathrm{O}_{2}\right)$. As discussed above, during combustion processes many different types of molecular pollutants are able to bind to transition metal-containing particles to form PM-containing EPFRs [22] and these formed EPFRs have been shown to produce a net output of ROS species in aqueous media [79]. The exact chemical composition and size of the various PM induce different amounts and types of oxidative stress. In lungs of neonatal animals and human bronchoepithelial cell lines (BEAS-2B) exposed to EPFRs, we have observed increased oxida tive stress following exposure to combustion generated PM [70, 72]. Indicators of oxidative stress included increases in the ratio of oxidized to reduced glutathione, markers of lipid peroxidation (e.g., 8-isoprostanes), and decreases in antioxidant enzyme activity including superoxide dismutase (SOD), catalase, and glutathione peroxidase. These effects were specifically related to the presence of the EPFR, since size-controlled non-EPFR particles failed to induce significant amounts of oxidative stress either in vivo or in vitro.

The overall role of oxidative stress in the development/exacerbation of lung disease is becoming apparent. Lipid peroxidation indicators such as malondialdehyde have been observed as biomarkers for PM-induced increases in oxidative stress in children with asthma [80]. This is thought to happen as both direct and indirect damage to the lung parenchyma; PM reacts directly with tissue to produce hydroxyl radicals via surface chemistry and indirectly through the actions of inflammatory cell influx. It has also been suggested that the ability to handle oxidative stress is altered in the lungs of asthmatics [81], leading to excessive ROS and its downstream effects (i.e., airway remodeling). 
Other studies have shown a relationship between oxidative stress and both innate and adaptive immune function. In particular, ozone $\left(\mathrm{O}_{3}\right)$ exposure induces increased cell surface expression of proteins intricately involved in sensing invading pathogens (e.g., toll-like receptor 4 (TLR4)). With $\mathrm{O}_{3}$ challenge, TLR4 expression increases and is responsible for enhanced immune responses to inhaled allergens in mice [82]. This effect has also been observed in healthy human subjects exposed to $\mathrm{O}_{3}[83,84]$. Oxidative stress also mediates the release of proinflammatory cytokines and increases antigen presentation because of immunosuppressive cytokine interleukin 10 (IL-10) downregulation leading to increased sensitivity and inflammation [85]. The role of oxidative stress and defense from oxidative damage is also an important factor in viral infection as demonstrated by higher viral burden in mice with antioxidantdeficient diets [86] and the attenuation of infection with treatment with the antioxidant glutathione [87].

PM exposure can also lead to changes in the development of adaptive immunity. Diesel exhaust particles, ambient $\mathrm{PM}$, and $\mathrm{O}_{3}$ have all been shown to act as adjuvants in rodent models of inflammatory airways disease $[88,89]$. More recent studies have demonstrated the direct effects of PM on mediators of adaptive immunity. With PM exposure, pulmonary dendritic cells (DCs), the professional antigen presenting cells of the immune system, increase in number and activation status [90], whereas T cells demonstrate greater proliferative ability [91]. We have also observed the exacerbating potential of EPFRcontaining PM during coexposure with allergen (OVA) in sensitized adults (data not shown). Interestingly, while these adjuvant-like effects of PM foster a heightened inflammatory response in adults, the infant immune system is very different and such heightened inflammatory responses can be quite detrimental in inhibiting adequate respiratory gas exchange and are thus often suppressed.

While our data suggest EPFR-mediated oxidative damage to neonatal lungs, there exist a plethora of data demonstrating that neonates are more resistant to oxidative damage as compared to adults $[92,93]$. However, the actual data on this subject are less clear. SOD activity in most strains of mice increases naturally with age and peaks at 25 weeks of age [94], and SOD-2 has been shown to be induced by cytokines including IL-1 $\beta$ and TNF $a$ both in vitro [95] and in vivo [96] models of hyperoxia; and neonates express these cytokines in higher amounts than adult mice [93]. Cumulatively, these data suggests an "oxidative-resistant" phenotype and that during this unique developmental period, the neonate is better equipped at handling additional oxidative damage to an extent because their bodies are primed to prepare for their first encounter with oxygen (i.e., SOD-1 activity is "programmed" to increase shortly after birth and the signals for SOD-2 induction are easily/ rapidly produced). This is contrary to adults where the oxidant/antioxidant balance has been well established, and subsequent insults prove detrimental.

Although neonatal mice have been shown to be more resistant to oxidative stress, severe focal alveolitis has been observed in response to hyperoxia indicating that pulmonary injury still occurs and is a major concern given the developmental status of the lung [93]. Consistent with this finding, our data show EPFR-containing PM cause alveolar septal destruction at a much higher degree than non-EPFR PM [70],, suggesting some oxidative component.

\section{Infant Immunity: An Age Naturally at Risk}

Shortly after birth, the neonatal immune system is bombarded with antigens, particularly at surfaces with high external exposure such as the respiratory tract. Neonates and infants must deal with pathogens using both innate immunity, mediated by pattern recognition receptors including TLRs, and adaptive immunity, mediated by helper and cytotoxic T cells and B cells. As previously stated, the infant immune system is very different from that of the adult. 
Innate immunity in the infant is impaired and characterized by selective TLR signaling (i.e., reduced overall TLR expression; responses to TLR8 ligands, and little-to-no responses to TLR1-7 ligands) and reduced ability to produce proinflammatory and Th1 cytokines (TNF $a$, IFN $\gamma$ ) upon TLR stimulation [97]. In addition, adaptive immunity in the infants is also very different from that of a mature adult. Neonates have impaired Th1 (IFN- $\gamma$, IL-12) responses but preserved Th2 responses (IL-4, IL-13) due to epigenetic differences (hypermethylation and hypomethylation, respectively) at cytokine regulatory regions [98-102]. This early bias is thought to be a result, at least in part, of the actions of immature DCs. Neonatal DCs display attenuated recruitment to the lung $[103,104]$ and a lower production of IL-12 leading to suppressed Th1 responses and resulting in Th2-biased responses [105]. In addition to suppressed Th1 responses, PM has been shown to suppress regulatory T cells (Treg) through hypermethylation of the Treg-transcription factor Foxp3 in the peripheral blood of children with asthma [106]. Our own data suggest that PM exposure in neonates initially causes an enhanced Treg response followed by a suppression of effector $\mathrm{T}$ helper (Th1 and Th2) responses to antigen such as influenza or ovalbumin. The implications of this are that early life exposure to PM creates a suppressive immune environment in the lung whereby the infant immune system cannot generate a protective effector $\mathrm{T}$ cell response to certain antigens/pathogens, resulting in enhanced disease. Since adaptive immunity relies on this initial response to "adapt," reexposure to the same antigen at a subsequent time point invokes an altered, more heterogeneous immune response that is also less protective (Figure 4). Whether this phenomena is PM composition-specific remains to be seen.

\section{Size of PM Is Important in Predicting Respiratory Impact}

We have previously reported that in a human laryngeal epithelial cell line, EPFR-containing particles $2.5 \mu \mathrm{m}$ in diameter $\left(\mathrm{EPFR}_{2.5}\right)$ are able to continuously generate $\mathrm{H}_{2} \mathrm{O}_{2}$, while modifying the activities of antioxidant enzymes associated with the neutralization of $\mathrm{H}_{2} \mathrm{O}_{2}$ (i.e., catalase) [76]. No significant change in the activity of SOD was observed suggesting that $\mathrm{O}_{2}{ }^{-}$is not generated in exposed cells. The significant generation of oxidized phospholipids (i.e., 8-isoprostanes) in the culture supernatants, along with the fact that $\mathrm{H}_{2} \mathrm{O}_{2}$ readily diffuses across the cell membrane, indicated that $\mathrm{EPFR}_{2.5}$ induces the generation of ROS outside of the cell. In vivo studies demonstrated that EPFR 2.5 induces only limited effects on pulmonary redox balance, increasing SOD activity and decreasing catalase activity, and not altering glutathione peroxidase activity or glutathione balance [76].

In contrast, our data using EPFR-containing particles $0.2 \mu \mathrm{m}$ in diameter $\left(\mathrm{EPFR}_{0.2}\right)$ have shown marked effects including drastic increases in oxidative stress and significant airway remodeling [70, 72]. EPFR 0.2 exposure increased the oxidized: reduced glutathione ratio and the level of the lipid peroxidation marker, 8-isoprostanes, in our neonatal rodent exposure model. In association with oxidative stress, we observed epithelial-to-mesenchymal transitions in vitro in $\mathrm{EPFR}_{0.2}$-exposed primary neonatal epithelial cells and in vivo in $\mathrm{EPFR}_{0.2}$-exposed neonatal mice and rats [72]. With multiple days of exposure, smooth muscle mass underlying the bronchial epithelium was increasingly greater and septal lesioning was evident in the alveoli.

Cumulatively, these data indicate that EPFR 2.5 generates $\mathrm{H}_{2} \mathrm{O}_{2}$ in the lungs of exposed neonatal animals whereas $\mathrm{EPFR}_{0.2}$ are able to penetrate much deeper into alveoli altering antioxidant capabilities. More interestingly, our data suggest that the pulmonary antioxidant defense system exhibits site-specific activity (i.e., catalase is essential in neutralization of ROS generated in the epithelial cells of the trachea and bronchi, and glutathione peroxidase is the main antioxidant involved in detoxification of oxidants in the alveolar region). This is supported by other published observations [107-109] and further suggests that the impact effect of EPFRs is limited to their site of deposition, which in the neonatal rodent lung means that EPFR 2.5 affects mainly the terminal bronchioles and $\mathrm{EPFR}_{0.2}$ affects the 
developing acinar structures. Our results are supported by recent experimental data demonstrating that ultrafine particle deposition occurs in the developing alveoli in neonatal rat lungs [110]. The human infant lung and respiratory system are obviously larger than that of an adult rat/mouse, much less an infant rat/mouse, suggesting that the independent size effects observed in the rodent models will occur simultaneously in the human infant. Various models of age-dependent particulate deposition in different lung compartments have shown that infants are alarmingly twice as susceptible to ultrafine particle deposition compared to adults and that most accumulation occurs in the alveolar region of the lower airways [111].

\section{Barrier Dysfunction and Airway Disease}

The respiratory epithelium is the first layer of defense against pollutants and aeroallergens. The protective function of the epithelium is maintained through the expression of proteins that allow for tight cell-cell adhesion (E-cadherin, $\beta$-catenin, zona occludins $1-3)$. Patients with asthma readily display reduced expression of these junctional proteins [112], and confluent cultures of cells from asthmatics display decreased transepithelial resistance, which indicates monolayer permeability and a heightened vulnerability to antigen and possibly pathogen access to the basement membrane [113]. Cigarette smoke extract (which contains EPFR-containing PMs) induces decreased transepithelial resistance and increased permeability to aeroallergens such as house dust mite (HDM) in vitro [114].

Our own research using EPFRs in an acute animal exposure model has demonstrated damaging effects of PM on airway epithelium [72]. Within 4 days of exposure, the cells lining the epithelium appear to be highly proliferative with decreased cell:cell junctions and increased epithelial membrane permeability. In subsequent exposure days, this is accompanied by a significant increase in airway remodeling made evident by massive increases in smooth muscle cell mass and number surrounding the airways (Figure 5).

Interestingly, disruption of the bronchial epithelium also strongly effects epithelial:DC interactions. Such interactions are crucial in dictating DC maturation and the ensuing immune response. At homeostatic baseline, free $\beta$-catenin in the cytosol of airway DCs is scarce, since it is either tethered to the cell membrane by E-cadherin [115] (which allows adherence to epithelial cells) or it is targeted for proteolytic degradation [116]. Cytosolic $\beta$ catenin is only observed under conditions of disrupted E-cadherin-mediated adhesion of epithelial cells and DCs or when wingless (Wnt) signaling is activated. Accumulation of cytosolic $\beta$-catenin eventually results in nuclear translocation and the initiation of various transcription events including Serpine 1 and Snail1 [115] and is strongly associated with IL-10+ regulatory DCs [117]. Since many aeroallergens, including HDM, display intrinsic protease activity as well as signaling capabilities that can drive epithelialto-mesenchymal transition [118], it must be noted that the continuous interaction between these two factors could be synergistic in promoting airway dysfunction and remodeling as well as affecting development of adaptive immune responses. This is something that we are vigorously investigating.

\section{CONCLUSION AND PERSPECTIVE}

EPFR-PM exposure disproportionately affects infants and children and is the cause of significant global mortality and morbidity. Infants/neonates represent a sensitive life stage with unique PM-induced pulmonary disease. Knowledge of the impact of PM on the protective epithelial layer of the respiratory tract along with how that damage modulates long-term immune responses should lead to a focus on how these responses affect the developing neonatal lung and immune system. While much correlative epidemiological data exist, there is currently little-to-no literature establishing a mechanism in infants. Our studies 
have shown that the influence of EPFR-containing PM on the developing epithelium proves to be of great significance in modifying functional physiology as well as immunity. Ultimately, understanding infant susceptibility and how it affects allergic sensitization/ asthma will open doors to new treatments and preventative therapeutics and more importantly, help promote and mold new legislative policies aimed at reducing environmental exposures to reduce these preventable adverse health consequences in addition to saving millions in healthcare dollars.

PM-induced pulmonary disease is a neglected area of global health that affects a large proportion of the world's population. It has become increasingly clear that properties of the various PM are responsible for the observed health effects. This presents a challenge to researchers due to the extreme variability in content of "real-world" PM samples. Differences in sampling methods, extraction methods, dosing concentrations, exposure models, etc. could prove to be monumentally responsible for the variability seen in experimental results. Combustion, laboratory-generated PM offers some advantages such as increased reproducibility but lacks the full spectra of "ingredients" that may also prove to be vitally important in the initiation of health effects. Looking forward, the most pressing areas of research are

- Improved exposure assessment methodologies:

- to more accurately assess airborne PM associated toxicants (e.g., EPFRs)

- to understand how sample collection, extraction, and other downstream treatments alter the chemical species of the sample

- to assess the effect of "storage time" on the biological activity of the environmental samples

- Additional toxicological studies:

- to help determine acute and long-term health risks

- to develop viable intervention therapeutics

- to identify biomarkers to aid epidemiological studies and determine level of present and past exposure

- Additional epidemiological studies to examine the effect on:

- infectious disease severity and outcomes

- growth and development

- other disease states (e.g., diabetes, cardiovascular disease)

These important issues must be addressed in order for accurate and unbiased conclusions to be drawn from PM research and for the true health impacts of EPFR-particle systems to be elucidated.

\section{Acknowledgments}

Contract Grant Sponsor: NIEHS.

Contract Grant Numbers: R01ES015050 (to SAC), P42ES013648 (to BD and SAC).

Contract Grant Sponsor: Louisiana Board of Regents.

Contract Grant Number: LEQSF (2009-14)-GF-08 (to JS).

Contract Grant Sponsor: NIAAA. 
Contract Grant Number: AA007577 (to GL).

The contents of this manuscript are solely the responsibility of the authors and do not necessarily represent the official views of NIH or the State of Louisiana.

\section{REFERENCES}

1. Kreyling WG, Semmler M, Moller W. Dosimetry and toxicology of ultrafine particles. J Aerosol Med. 2004; 17(2):140-152. [PubMed: 15294064]

2. Sanda MG, Restifo NP, Walsh JC, Kawakami Y, Nelson WG, Pardoll DM, Simons JW. Molecular characterization of defective antigen processing in human prostate cancer. J Natl Cancer Inst. 1995; 87(4):280-285. [PubMed: 7707419]

3. Nelson GW, Perelson AS. Modeling defective interfering virus therapy for AIDS: conditions for DIV survival. Math Biosci. 1995; 125(2):127-153. [PubMed: 7881191]

4. WHO. Air quality guidelines global update.. Report on a working group meeting; Bonn, Germany. October 18-20, 2005; Available at www.euro.who.int/_data/assets/pdf_file/0005/78638/E90038.pdf

5. Gisselquist D, Upham G, Potterat JJ. Efficiency of human immunodeficiency virus transmission through injections and other medical procedures: evidence, estimates, and unfinished business. Infect Control Hosp Epidemiol. 2006; 27(9):944-52. [PubMed: 16941321]

6. WHO. [May 22, 2012] Tackling the global clean air challenge. 2011. Available at www.who.int/ mediacentre/news/releases/2011/air_pollution_20110926/en/index.html

7. Martin WJ II, Glass RI, Balbus JM, Collins FS. Public health. A major environmental cause of death. Science. 2011; 334(6053):180-181. [PubMed: 21998373]

8. WHO. [May 22, 2012] Global health risks mortality and burden of disease attributable to selected major risks. 2008. update. Available at http://www.who.int/healthinfo/global_burden_disease/ GlobalHealthRisks_report_full.pdf

9. Sram RJ, Binkova B, Dejmek J, Bobak M. Ambient air pollution and pregnancy outcomes: a review of the literature. Environ Health Perspect. 2005; 113(4):375-382. [PubMed: 15811825]

10. Mishra V, Retherford RD. Does biofuel smoke contribute to anaemia and stunting in early childhood? Int J Epidemiol. 2007; 36(1):117-129. [PubMed: 17085456]

11. Lin HH, Ezzati M, Murray M. Tobacco smoke, indoor air pollution and tuberculosis: a systematic review and meta-analysis. PLoS Med. 2007; 4(1):e20. [PubMed: 17227135]

12. Brook RD, Franklin B, Cascio W, Hong Y, Howard G, Lipsett M, Luepker R, Mittleman M, Samet J, Smith SC Jr, Tager I. Expert Panel on Population and Prevention Science of the American Heart Association. Air pollution and cardiovascular disease. Circulation. 2004; 109(21):2655-2671. [PubMed: 15173049]

13. Pope CA, Thun MJ, Namboodiri MM, Dockery DW, Evans JS, Speizer FE, Heath CW. Particulate air pollution as a predictor of mortality in a prospective study of U.S. adults. Am J Resp Crit Care Med. 1995; 151(3):669-674. [PubMed: 7881654]

14. Pokhrel AK, Smith KR, Khalakdina A, Deuja A, Bates MN. Case-control study of indoor cooking smoke exposure and cataract in Nepal and India. Int J Epidemiol. 2005; 34(3):702-708. [PubMed: 15737974]

15. Saha A, Kulkarni PK, Shah A, Patel M, Saiyed HN. Ocular morbidity and fuel use: an experience from India. Occup Environ Med. 2005; 62(1):66-69. [PubMed: 15613613]

16. Valavanidis A, Fiotakis K, Vlachogianni T. Airborne particulate matter and human health: toxicological assessment and importance of size and composition of particles for oxidative damage and carcinogenic mechanisms. J Environ Sci Health C: Environ Carcinog Ecotoxicol Rev. 2008; 26(4):339-362. [PubMed: 19034792]

17. Franck U, Herbarth O, Roder S, Schlink U, Borte M, Diez U, Kramer U, Lehmann I. Respiratory effects of indoor particles in young children are size dependent. Sci Total Environ. 2011; 409(9): 1621-1631. [PubMed: 21316080]

18. Cass GR, Hughes LA, Bhave P, Kleeman MJ, Allen JO, Salmon LG. The chemical composition of atmospheric ultrafine particles. Philos Trans R Soc London, Ser A. 2000; 358(1775):2581-2592. 
19. Martens D, Prachar V, Amberg S, Oxynos K, Schramm KW, Kettrup A. Determination of pentachlorophenol (PCP) in samples of the environmental specimen bank using isotope dilution. Int J Environ Anal Chem. 1997; 68(4):415-427.

20. Squadrito GL, Cueto R, Dellinger B, Pryor WA. Quinoid redox cycling as a mechanism for sustained free radical generation by inhaled airborne particulate matter. Free Radic Biol Med. 2001; 31(9):1132-1138. [PubMed: 11677046]

21. Lomnicki S, Truong H, Vejerano E, Dellinger B. Copper oxide-based model of persistent free radical formation on combustion-derived particulate matter. Environ Sci Technol. 2008; 42(13): 4982-4988. [PubMed: 18678037]

22. Dellinger B, Pryor WA, Cueto R, Squadrito GL, Hegde V, Deutsch WA. Role of free radicals in the toxicity of airborne fine particulate matter. Chem Res Toxicol. 2001; 14(10):1371-7. [PubMed: 11599928]

23. Dellinger, B.; Pryor, W.; Cueto, R.; Squadrito, GL.; Deutsch, WA. In the role of combustiongenerated radicals in the toxicity of PM2.5.. Proceedings of the 28th International Symposium on Combustion 2000; 2000;

24. Dellinger B, Khachatryan L, Masko S, Lomnicki S. Free Radicals in Tobacco Smoke. Mini-Rev Org Chem. 2011; 8(4):427-433.

25. Pryor WA, Stone K, Zang LY, Bermudez E. Fractionation of aqueous cigarette tar extracts: fractions that contain the tar radical cause DNA damage. Chem Res Toxicol. 1998; 11(5):441-8. [PubMed: 9585474]

26. Valavanidis A, Fiotakis K, Bakeas E, Vlahogianni T. Electron paramagnetic resonance study of the generation of reactive oxygen species catalysed by transition metals and quinoid redox cycling by inhalable ambient particulate matter. Redox Rep. 2005; 10(1):37-51. [PubMed: 15829110]

27. Lingard JJN, Tomlin AS, Clarke AG, Healey K, Hay AWM, Wild CP, Routledge MN. A study of trace metal concentration of urban airborne particulate matter and its role in free radical activity as measured by plasmid strand break assay. Atmos Environ. 2005; 39(13):2377-2384.

28. Valavanidis A, Iliopoulos N, Gotsis G, Fiotakis K. Persistent free radicals, heavy metals and PAHs generated in particulate soot emissions and residue ash from controlled combustion of common types of plastic. J Hazard Mater. 2008; 156(1-3):277-284. [PubMed: 18249066]

29. Valavanidis A, Fiotakis K, Vlahogianni T, Papadimitriou V, Pantikaki V. Determination of selective quinones and quinoid radicals in airborne particulate matter and vehicular exhaust particles. Environ Chem. 2006; 3(2):118-123.

30. Maskos Z, Khachatryan L, Cueto R, Pryor WA, Dellinger B. Radicals from the pyrolysis of tobacco. Energy Fuels. 2005; 19(3):791-799.

31. Pryor WA, Prier DG, Church DF. Electron-spin resonance study of mainstream and sidestream cigarette smoke: nature of the free radicals in gas-phase smoke and in cigarette tar. Environ Health Perspect. 1983; 47:345-355. [PubMed: 6297881]

32. Maestrelli P, Canova C, Scapellato ML, Visentin A, Tessari R, Bartolucci GB, Simonato L, Lotti M. Personal exposure to particulate matter is associated with worse health perception in adult asthma. J Investig Allergol Clin Immunol. 2011; 21(2):120-128.

33. Di Giampaolo L, Quecchia C, Schiavone C, Cavallucci E, Renzetti A, Braga M, Di Gioacchino M. Environmental pollution and asthma. Int J Immunopathol Pharmacol. 2011; 24(1 Suppl):31S-38S. [PubMed: 21329563]

34. Knol AB, de Hartog JJ, Boogaard H, Slottje P, van der Sluijs JP, Lebret E, Cassee FR, Wardekker JA, Ayres JG, Borm PJ, Brunekreef B, Donaldson K, Forastiere F, Holgate ST, Kreyling WG, Nemery B, Pekkanen J, Stone V, Wichmann HE, Hoek G. Expert elicitation on ultrafine particles: likelihood of health effects and causal pathways. Part Fibre Toxicol. 2009; 6:19. [PubMed: 19630955]

35. Salihu HM, August EM, Jeffers DF, Mbah AK, Alio AP, Berry E. Effectiveness of a Federal Healthy Start program in reducing primary and repeat teen pregnancies: our experience over the decade. J Pediatr Adolesc Gynecol. 2011; 24(3):153-160. [PubMed: 21397532]

36. Rich DQ, Demissie K, Lu S-E, Kamat L, Wartenberg D, Rhoads GG. Ambient air pollutant concentrations during pregnancy and the risk of fetal growth restriction. J Epidemiol Community Health. 2009; 63(6):488-496. [PubMed: 19359274] 
37. Bennett WD, Zeman KL. Deposition of fine particles in children spontaneously breathing at rest. Inhalation Toxicol. 1998; 10(9):831-842.

38. Yi O, Kim H, Ha E. Does area level socioeconomic status modify the effects of PM10 on preterm delivery? Environ Res. 2010; 110(1):55-61. [PubMed: 19878932]

39. Ritz B, Wilhelm M, Zhao Y. Air pollution and infant death in southern California, 1989-2000. Pediatrics. 2006; 118(2):493-502. [PubMed: 16882800]

40. Dudek, RW. Embryology. Lippincott Williams and Wilkins; Riverwoods, IL: 2011.

41. Sly PD. The early origins of asthma: who is really at risk? Curr Opin Allergy Clin Immunol. 2011; 11(1):24-28. [PubMed: 21150438]

42. Andersen ZJ, Wahlin P, Raaschou-Nielsen O, Scheike T, Loft S. Ambient particle source apportionment and daily hospital admissions among children and elderly in Copenhagen. J Expo Sci Environ Epidemiol. 2007; 17(7):625-636. [PubMed: 17495872]

43. Nicolai T. Air pollution and respiratory disease in children: what is the clinically relevant impact? Pediatr Pulmonol Suppl. 1999; 18:9-13. [PubMed: 10093083]

44. Silverman RA, Ito K. Age-related association of fine particles and ozone with severe acute asthma in New York City. J Allergy Clin Immunol. 2010; 125(2):367-373. e5. [PubMed: 20159246]

45. Yeh KW, Chang CJ, Huang JL. The association of seasonal variations of asthma hospitalization with air pollution among children in Taiwan. Asian Pac J Allergy Immunol. 2011; 29(1):34-41. [PubMed: 21560486]

46. Atkinson RW, Anderson HR, Sunyer J, Ayres J, Baccini M, Vonk JM, Boumghar A, Forastiere F, Forsberg B, Touloumi G, Schwartz J, Katsouyanni K. Acute effects of particulate air pollution on respiratory admissions: results from APHEA 2 project. Air Pollution and Health: a European Approach. Am J Respir Crit Care Med. 2001; 164(10, Pt 1):1860-1866. [PubMed: 11734437]

47. Son JY, Bell ML, Lee JT. Individual exposure to air pollution and lung function in Korea: spatial analysis using multiple exposure approaches. Environ Res. 2010; 110(8):739-49. [PubMed: 20832787]

48. He QQ, Wong TW, Du L, Jiang ZQ, Gao Y, Qiu H, Liu WJ, Wu JG, Wong A, Yu TS. Effects of ambient air pollution on lung function growth in Chinese schoolchildren. Respir Med. 2010; 104(10):1512-1520. [PubMed: 20471233]

49. Liu L, Poon R, Chen L, Frescura AM, Montuschi P, Ciabattoni G, Wheeler A, Dales R. Acute effects of air pollution on pulmonary function, airway inflammation, and oxidative stress in asthmatic children. Environ Health Perspect. 2009; 117(4):668-674. [PubMed: 19440509]

50. Dales R, Chen L, Frescura AM, Liu L, Villeneuve PJ. Acute effects of outdoor air pollution on forced expiratory volume in $1 \mathrm{~s}$ : a panel study of schoolchildren with asthma. Eur Respir J. 2009; 34(2):316-323. [PubMed: 19251781]

51. Mauad T, Rivero DH, de Oliveira RC, Lichtenfels AJ, Guimaraes ET, de Andre PA, Kasahara DI, Bueno HM, Saldiva PH. Chronic exposure to ambient levels of urban particles affects mouse lung development. Am J Respir Crit Care Med. 2008; 178(7):721-728. [PubMed: 18596224]

52. Lee D, Wallis C, Wexler AS, Schelegle ES, Van Winkle LS, Plopper CG, Fanucchi MV, Kumfer B, Kennedy IM, Chan JK. Small particles disrupt postnatal airway development. J Appl Physiol. 2010; 109(4):1115-1124. [PubMed: 20634362]

53. Mena MA, Woll F, Cok J, Ferrufino JC, Accinelli RA. Histopathological lung changes in children due to biomass fuel. Am J Respir Crit Care Med. 2012; 185(6):687-688. [PubMed: 22422909]

54. Brauer M, Hoek G, Van Vliet P, Meliefste K, Fischer PH, Wijga A, Koopman LP, Neijens HJ, Gerritsen J, Kerkhof M, Heinrich J, Bellander T, Brunekreef B. Air pollution from traffic and the development of respiratory infections and asthmatic and allergic symptoms in children. Am J Respir Crit Care Med. 2002; 166(8):1092-1098. [PubMed: 12379553]

55. Karr CJ, Rudra CB, Miller KA, Gould TR, Larson T, Sathyanarayana S, Koenig JQ. Infant exposure to fine particulate matter and traffic and risk of hospitalization for RSV bronchiolitis in a region with lower ambient air pollution. Environ Res. 2009; 109(3):321-327. [PubMed: 19211100]

56. Pope CA 3rd, Burnett RT, Thurston GD, Thun MJ, Calle EE, Krewski D, Godleski JJ. Cardiovascular mortality and long-term exposure to particulate air pollution: epidemiological 
evidence of general pathophysiological pathways of disease. Circulation. 2004; 109(1):71-77. [PubMed: 14676145]

57. Woodruff TJ, Darrow LA, Parker JD. Air pollution and postneonatal infant mortality in the United States, 1999-2002. Environ Health Perspect. 2008; 116(1):110-115. [PubMed: 18197308]

58. Bruce N, Weber M, Arana B, Diaz A, Jenny A, Thompson L, McCracken J, Dherani M, Juarez D, Ordonez S, Klein R, Smith KR. Pneumonia case-finding in the RESPIRE Guatemala indoor air pollution trial: standardizing methods for resource-poor settings. Bull World Health Org. 2007; 85:535-544. [PubMed: 17768502]

59. McCracken J, Schwartz J, Mittleman M, Ryan L, Artiga AD, Smith KR, et al. Biomass smoke exposure and acute lower respiratory infections among guatemalan children. Epidemiology. 2007; 18(5):S185.

60. Harrod KS, Jaramillo RJ, Rosenberger CL, Wang SZ, Berger JA, McDonald JD, Reed MD. Increased susceptibility to RSV infection by exposure to inhaled diesel engine emissions. Am J Respir Cell Mol Biol. 2003; 28(4):451-463. [PubMed: 12654634]

61. Hahon N, Booth JA, Green F, Lewis TR. Influenza virus infection in mice after exposure to coal dust and diesel engine emissions. Environ Res. 1985; 37(1):44-60. [PubMed: 2581774]

62. Lambert AL, Mangum JB, DeLorme MP, Everitt JI. Ultrafine carbon black particles enhance respiratory syncytial virus-induced airway reactivity, pulmonary inflammation, and chemokine expression. Toxicol Sci. 2003; 72(2):339-346. [PubMed: 12655033]

63. Lambert AL, Trasti FS, Mangum JB, Everitt JI. Effect of preexposure to ultrafine carbon black on respiratory syncytial virus infection in mice. Toxicol Sci. 2003; 72(2):331-338. [PubMed: 12660365]

64. Sheffield P, Roy A, Wong K, Trasande L. Fine particulate matter pollution linked to respiratory illness in infants and increased hospital costs. Health Aff (Millwood). 2011; 30(5):871-878. [PubMed: 21543422]

65. Gowdy KM, Krantz QT, King C, Boykin E, Jaspers I, Linak WP, Gilmour MI. Role of oxidative stress on diesel-enhanced influenza infection in mice. Part Fibre Toxicol. 2010; 7:34. [PubMed: 21092162]

66. Ciencewicki J, Jaspers I. Air pollution and respiratory viral infection. Inhal Toxicol. 2007; 19(14): 1135-1146. [PubMed: 17987465]

67. Kaan PM, Hegele RG. Interaction between respiratory syncytial virus and particulate matter in guinea pig alveolar macrophages. Am J Respir Cell Mol Biol. 2003; 28(6):697-704. [PubMed: 12760967]

68. Phaybouth V, Wang SZ, Hutt JA, McDonald JD, Harrod KS, Barrett EG. Cigarette smoke suppresses Th1 cytokine production and increases RSV expression in a neonatal model. Am J Physiol Lung Cell Mol Physiol. 2006; 290(2):L222-L231. [PubMed: 16126789]

69. Wang D, Cummins C, Bayliss S, Sandercock J, Burls A. Immunoprophylaxis against respiratory syncytial virus (RSV) with palivizumab in children: a systematic review and economic evaluation. Health Technol Assess. 2008; 12(36):iii, ix-x, 1-86.

70. Balakrishna S, Saravia J, Thevenot P, Ahlert T, Lominiki S, Dellinger B, Cormier SA. Environmentally persistent free radicals induce airway hyperresponsiveness in neonatal rat lungs. Particle Fibre Toxicol. 2011; 8:11.

71. Gauderman WJ, Avol E, Gilliland F, Vora H, Thomas D, Berhane K, McConnell R, Kuenzli N, Lurmann F, Rappaport E, Margolis H, Bates D, Peters J. The effect of air pollution on lung development from 10 to 18 years of age. New Eng J Med. 2004; 351(11):1057-1067. [PubMed: 15356303]

72. Thevenot PT, Saravia J, Jin N, Giaimo JD, Chustz RE, Mahne S, Kelley MA, Hebert VY, Dellinger B, Dugas TR, Demayo FJ, Cormier SA. Radical-containing PM0.2 initiates epithelial-tomesenchymal transitions in airway epithelial cells. Am J Respir Cell Mol Biol. 2012 First published online October 18, 2012. doi:10.1165/rcmb.2012-0052OC.

73. Mazzoli-Rocha F, Fernandes S, Einicker-Lamas M, Zin WA. Roles of oxidative stress in signaling and inflammation induced by particulate matter. Cell Biol Toxicol. 2010; 26(5):481-498. [PubMed: 20340042] 
74. Moller P, Jacobsen NR, Folkmann JK, Danielsen PH, Mikkelsen L, Hemmingsen JG, Vesterdal LK, Forchhammer L, Wallin H, Loft S. Role of oxidative damage in toxicity of particulates. Free Radic Res. 2010; 44(1):1-46. [PubMed: 19886744]

75. Fahmy B, Cormier SA. Copper oxide nanoparticles induce oxidative stress and cytotoxicity in airway epithelial cells. Toxicol In Vitro. 2009; 23(7):1365-1371. [PubMed: 19699289]

76. Fahmy B, Ding L, You D, Lomnicki S, Dellinger B, Cormier SA. In vitro and in vivo assessment of pulmonary risk associated with exposure to combustion generated fine particles. Environ Toxicol Pharmacol. 2010; 29(2):173-182. [PubMed: 20369027]

77. Balakrishna S, Lomnicki S, McAvey K, Cole R, Dellinger B, Cormier S. Environmentally persistent free radicals amplify ultrafine particle mediated cellular oxidative stress and cytotoxicity. Particle Fibre Toxicol. 2009; 6(1):11.

78. Wang P, Thevenot P, Saravia J, Ahlert T, Cormier S. Radical containing particles activate DCs and enhance Th17 inflammation in a mouse model of asthma. Am J Resp Cell Mol Biol. 2011; 45(5): 977-83.

79. Khachatryan L, Vejerano E, Lomnicki S, Dellinger B. Environmentally persistent free radicals (EPFRs). 1. Generation of reactive oxygen species in aqueous solutions. Environ Sci Technol. 2011; 45(19):8559-66. [PubMed: 21823585]

80. Romieu I, Barraza-Villarreal A, Escamilla-Nunez C, Almstrand AC, Diaz-Sanchez D, Sly PD, Olin AC. Exhaled breath malondialdehyde as a marker of effect of exposure to air pollution in children with asthma. J Allergy Clin Immunol. 2008; 121(4):903-9. e6. [PubMed: 18234317]

81. Dworski R. Oxidant stress in asthma. Thorax. 2000; 55(Suppl 2):S51-S53. [PubMed: 10992559]

82. Hollingsworth JW, Maruoka S, Li Z, Potts EN, Brass DM, Garantziotis S, Fong A, Foster WM, Schwartz DA. Ambient ozone primes pulmonary innate immunity in mice. J Immunol. 2007; 179(7):4367-75. [PubMed: 17878331]

83. Lay JC, Alexis NE, Kleeberger SR, Roubey RA, Harris BD, Bromberg PA, Hazucha MJ, Devlin $\mathrm{RB}$, Peden DB. Ozone enhances markers of innate immunity and antigen presentation on airway monocytes in healthy individuals. J Allergy Clin Immunol. 2007; 120(3):719-722. [PubMed: 17586033]

84. Hernandez ML, Harris B, Lay JC, Bromberg PA, Diaz-Sanchez D, Devlin RB, Kleeberger SR, Alexis NE, Peden DB. Comparative airway inflammatory response of normal volunteers to ozone and lipopolysaccharide challenge. Inhal Toxicol. 2010; 22(8):648-656. [PubMed: 20540623]

85. Saxon A, Diaz-Sanchez D. Air pollution and allergy: you are what you breathe. Nat Immunol. 2005; 6(3):223-226. [PubMed: 15716966]

86. Beck MA, Handy J, Levander OA. The role of oxidative stress in viral infections. Ann N Y Acad Sci. 2000; 917:906-912. [PubMed: 11268420]

87. Cai J, Chen Y, Seth S, Furukawa S, Compans RW, Jones DP. Inhibition of influenza infection by glutathione. Free Radic Biol Med. 2003; 34(7):928-936. [PubMed: 12654482]

88. Harkema JR, Wagner JG, Kaminski NE, Morishita M, Keeler GJ, McDonald JD, Barrett EG. Effects of concentrated ambient particles and diesel engine exhaust on allergic airway disease in Brown Norway rats. Resir Rep Health Eff Inst. 2009; (145):5-55.

89. Jang AS, Choi IS, Takizawa H, Rhim T, Lee JH, Park SW, Park CS. Additive effect of diesel exhaust particulates and ozone on airway hyperresponsiveness and inflammation in a mouse model of asthma. J Korean Med Sci. 2005; 20(5):759-763. [PubMed: 16224148]

90. Provoost S, Maes T, Willart MA, Joos GF, Lambrecht BN, Tournoy KG. Diesel exhaust particles stimulate adaptive immunity by acting on pulmonary dendritic cells. J Immunol. 2010; 184(1): 426-432. [PubMed: 19949085]

91. Deiuliis JA, Kampfrath T, Zhong J, Oghumu S, Maiseyeu A, Chen LC, Sun Q, Satoskar AR, Rajagopalan S. Pulmonary T cell activation in response to chronic particulate air pollution. Am J Physiol Lung Cell Mol Physiol. 2012; 302(4):L399-L409. [PubMed: 22160305]

92. Stevens JB, Autor AP. Proposed mechanism for neonatal rat tolerance to normobaric hyperoxia. Fed Proc. 1980; 39(13):3138-3143. [PubMed: 6253331]

93. Johnston CJ, Wright TW, Reed CK, Finkelstein JN. Comparison of adult and newborn pulmonary cytokine mRNA expression after hyperoxia. Exp Lung Res. 1997; 23(6):537-552. [PubMed: 9358235] 
94. Schisler NJ, Singh SM. Tissue-specific developmental regulation of superoxide dismutase (SOD-1 and SOD-2) activities in genetic strains of mice. Biochem Genet. 1985; 23(3-4):291-308. [PubMed: 4015619]

95. Visner GA, Dougall WC, Wilson JM, Burr IA, Nick HS. Regulation of manganese superoxide dismutase by lipopolysaccharide, interleukin-1, and tumor necrosis factor. Role in the acute inflammatory response. J Biol Chem. 1990; 265(5):2856-2864. [PubMed: 2406241]

96. Tsan MF, White JE, Treanor C, Shaffer JB. Molecular basis for tumor necrosis factor-induced increase in pulmonary superoxide dismutase activities. Am J Physiol. 1990; 259(6 Pt 1):L506L512. [PubMed: 2260678]

97. Levy O, Zarember KA, Roy RM, Cywes C, Godowski PJ, Wessels MR. Selective impairment of TLR-mediated innate immunity in human newborns: neonatal blood plasma reduces monocyte TNF-alpha induction by bacterial lipopeptides, lipopolysaccharide, and imiquimod, but preserves the response to R-848. J Immunol. 2004; 173(7):4627-4634. [PubMed: 15383597]

98. Belderbos M, Levy O, Bont L. Neonatal innate immunity in allergy development. Curr Opin Pediatr. 2009; 21(6):762-769. [PubMed: 19770766]

99. Becnel D, You D, Erskin J, Dimina DM, Cormier SA. A role for airway remodeling during respiratory syncytial virus infection. Respir Res. 2005; 6:122. [PubMed: 16242038]

100. You D, Becnel D, Wang K, Ripple M, Daly M, Cormier SA. Exposure of neonates to Respiratory Syncytial Virus is critical in determining subsequent airway response in adults. Respir Res. 2006; 7(1):107. [PubMed: 16893457]

101. You D, Ripple M, Balakrishna S, Troxclair D, Sandquist D, Ding L, Ahlert TA, Cormier SA. Inchoate CD8+ T cell responses in neonatal mice permit influenza-induced persistent pulmonary dysfunction. J Immunol. 2008; 181(5):3486-3494. [PubMed: 18714021]

102. Ripple M, You D, Honnegowda S, Giaimo J, Sewell A, Becnel DM, Cormier SA. Immunomodulation with IL-4Ra antisense oligonucleotide prevents respiratory syncytial virusmediated pulmonary disease. J Immunol. 2010; 185(8):4804-4811. [PubMed: 20861354]

103. Nelson DJ, Holt PG. Defective regional immunity in the respiratory tract of neonates is attributable to hyporesponsiveness of local dendritic cells to activation signals. J Immunol. 1995; 155(7):3517-3524. [PubMed: 7561047]

104. Upham JW, Rate A, Rowe J, Kusel M, Sly PD, Holt PG. Dendritic cell immaturity during infancy restricts the capacity to express vaccine-specific T-cell memory. Infect Immun. 2006; 74(2): 1106-1112. [PubMed: 16428758]

105. Lee HH, Hoeman CM, Hardaway JC, Guloglu FB, Ellis JS, Jain R, Divekar R, Tartar DM, Haymaker CL, Zaghouani H. Delayed maturation of an IL-12-producing dendritic cell subset explains the early Th2 bias in neonatal immunity. J Exp Med. 2008; 205(10):2269-2280. [PubMed: 18762566]

106. Nadeau K, McDonald-Hyman C, Noth EM, Pratt B, Hammond SK, Balmes J, Tager I. Ambient air pollution impairs regulatory T-cell function in asthma. J Allergy Clin Immunol. 2010; 126(4): 845-852. e10. [PubMed: 20920773]

107. Avissar N, Finkelstein JN, Horowitz S, Willey JC, Coy E, Frampton MW, Watkins RH, Khullar $\mathrm{P}, \mathrm{Xu}$ YL, Cohen HJ. Extracellular glutathione peroxidase in human lung epithelial lining fluid and in lung cells. Am J Physiol. 1996; 270(2, Pt 1):L173-L182. [PubMed: 8779985]

108. Baeza-Squiban A, Bonvallot V, Boland S, Marano F. Airborne particles evoke an inflammatory response in human airway epithelium. Activation of transcription factors. Cell Biol Toxicol. 1999; 15(6):375-380. [PubMed: 10811532]

109. Cohn LA, Kinnula VL, Adler KB. Antioxidant properties of guinea pig tracheal epithelial cells in vitro. Am J Physiol. 1994; 266(4 Pt 1):L397-L404. [PubMed: 8179017]

110. Semmler-Behnke M, Kreyling WG, Schulz H, Takenaka S, Butler JP, Henry FS, Tsuda A. Nanoparticle delivery in infant lungs. Proc Natl Acad Sci U S A. 2012; 109(13):5092-5097. [PubMed: 22411799]

111. Ginsberg GL, Asgharian B, Kimbell JS, Ultman JS, Jarabek AM. Modeling approaches for estimating the dosimetry of inhaled toxicants in children. J Toxicol Environ Health A. 2008; 71(3):166-195. [PubMed: 18097944] 
112. Swindle EJ, Collins JE, Davies DE. Breakdown in epithelial barrier function in patients with asthma: identification of novel therapeutic approaches. J Allergy Clin Immunol. 2009; 124(1): 23-34. quiz 35-36. [PubMed: 19560576]

113. Holgate ST, Roberts G, Arshad HS, Howarth PH, Davies DE. The role of the airway epithelium and its interaction with environmental factors in asthma pathogenesis. Proc Am Thorac Soc. 2009; 6(8):655-659. [PubMed: 20008870]

114. Gangl K, Reininger R, Bernhard D, Campana R, Pree I, Reisinger J, Kneidinger M, Kundi M, Dolznig H, Thurnher D, Valent P, Chen KW, Vrtala S, Spitzauer S, Valenta R, Niederberger V. Cigarette smoke facilitates allergen penetration across respiratory epithelium. Allergy. 2009; 64(3):398-405. [PubMed: 19120070]

115. Hammad H, Lambrecht BN. Dendritic cells and epithelial cells: linking innate and adaptive immunity in asthma. Nat Rev Immunol. 2008; 8(3):193-204. [PubMed: 18301423]

116. Nelson WJ, Nusse R. Convergence of Wnt, beta-catenin, and cadherin pathways. Science. 2004; 303(5663):1483-1487. [PubMed: 15001769]

117. Manicassamy S, Reizis B, Ravindran R, Nakaya H, Salazar-Gonzalez RM, Wang YC, Pulendran B. Activation of beta-catenin in dendritic cells regulates immunity versus tolerance in the intestine. Science. 2010; 329(5993):849-853. [PubMed: 20705860]

118. Heijink IH, van Oosterhout A, Kapus A. Epidermal growth factor receptor signalling contributes to house dust mite-induced epithelial barrier dysfunction. Eur Respir J. 2010; 36(5):1016-1026. [PubMed: 20351035] 


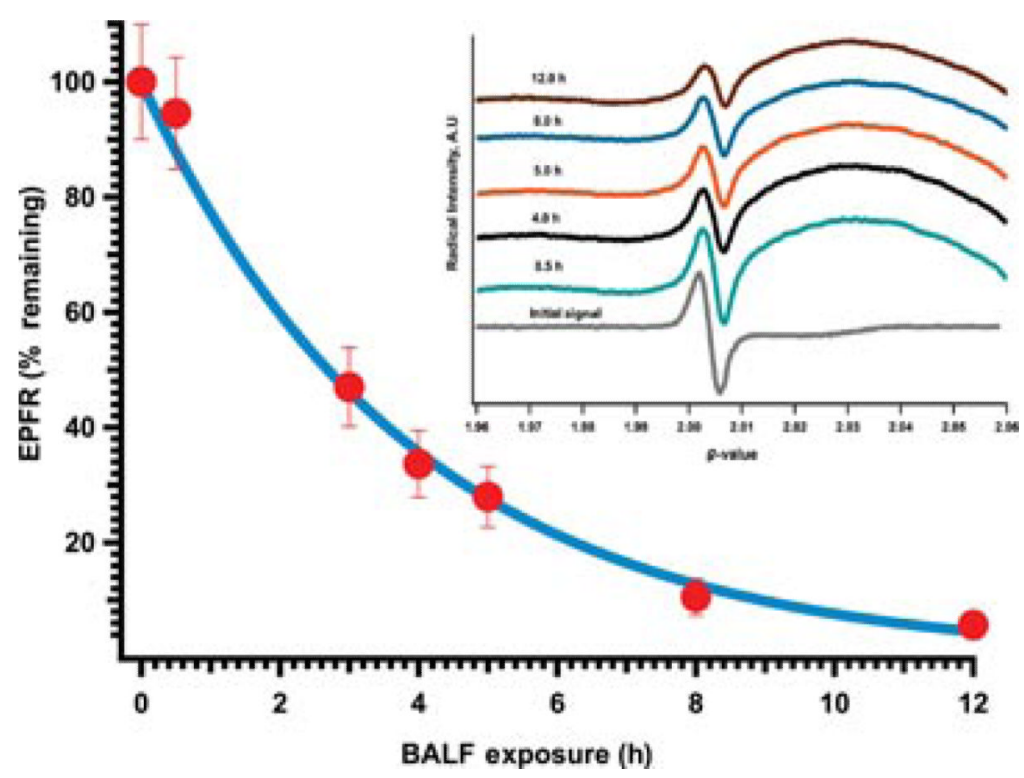

FIGURE 1.

Persistency of EPFRs in mouse BALF. EPFR-containing PM (2-MCP on 3\% CuO/silica) were suspended in BALF and shaken continuously. At the indicated times, samples were centrifuged for $5 \mathrm{~min}$; and the liquid fraction discarded and the particle fraction retained. Particles were frozen at $-25^{\circ} \mathrm{C}$ and dried in a vacuum for $12 \mathrm{~h}$ at room temperature. The analysis of the EPR analysis of the particles demonstrated the presence of paramagnetic signal with a characteristic $g$ value of 2.0042 and a peak width of $\sim 8$ Gauss (inset). These spectra were similar to preexposure samples and are characteristic to the presence of EPFRs associated with particles. The position and width of the radical signal was not affected by incubation in BALF; however, the intensity (i.e., the number of radicals) diminished with increasing incubation time. 


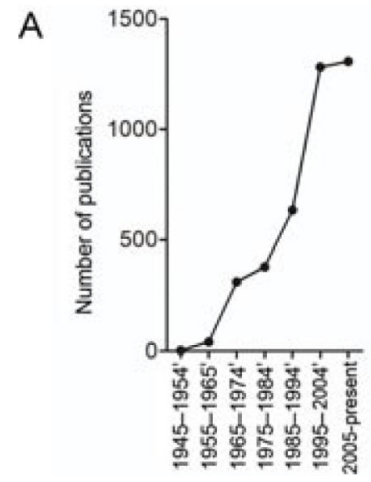

B

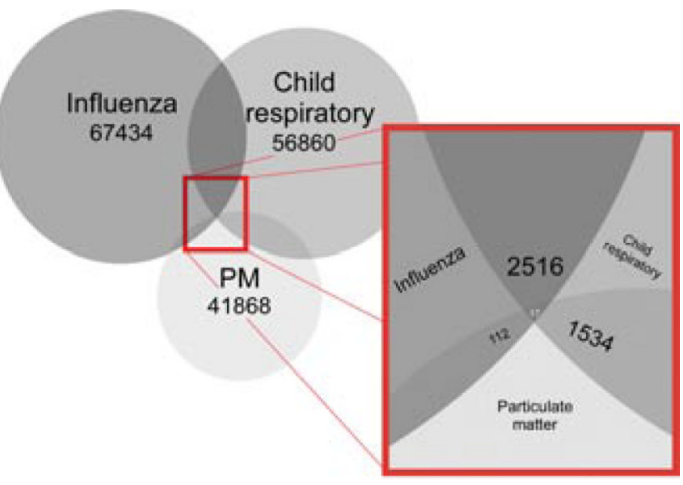

FIGURE 2.

Pubmed Search Results. (A) Number of publications available on asthma and particulate matter. Search conducted on May 23, 2012. (B). Number of published articles available on influenza and child respiratory and particulate matter. Search conducted on May 21, 2012. 


\section{Airway hyperreactivity}

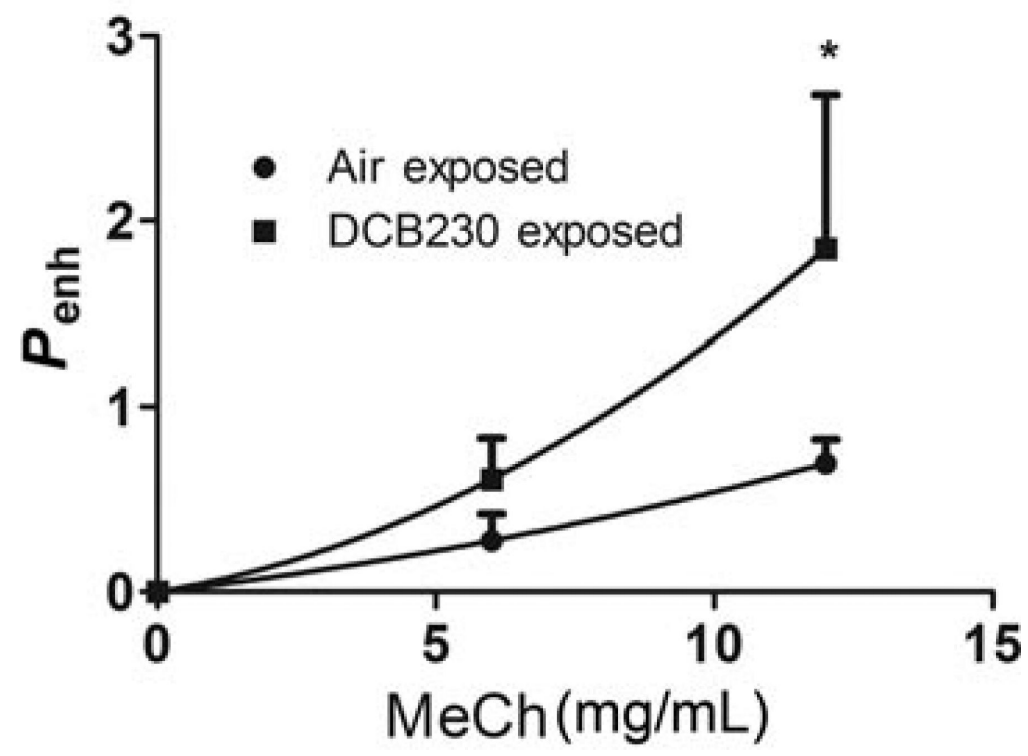

FIGURE 3.

Airways hyperreactivity following neonatal exposure to EPFR-containing PM persists in the adult. Neonatal rodents were exposed to EPFR-containing PM or control air for 7 consecutive days then allowed to mature to 8 weeks of age. Enhanced pause (Penh), a derived measure of airways hyperresponsiveness, was measured with increasing doses of inhaled methacholine using whole body plethysmography. $n=6-8$ animals/group. ${ }^{*} p<0.05$ Two-way ANOVA. 
A

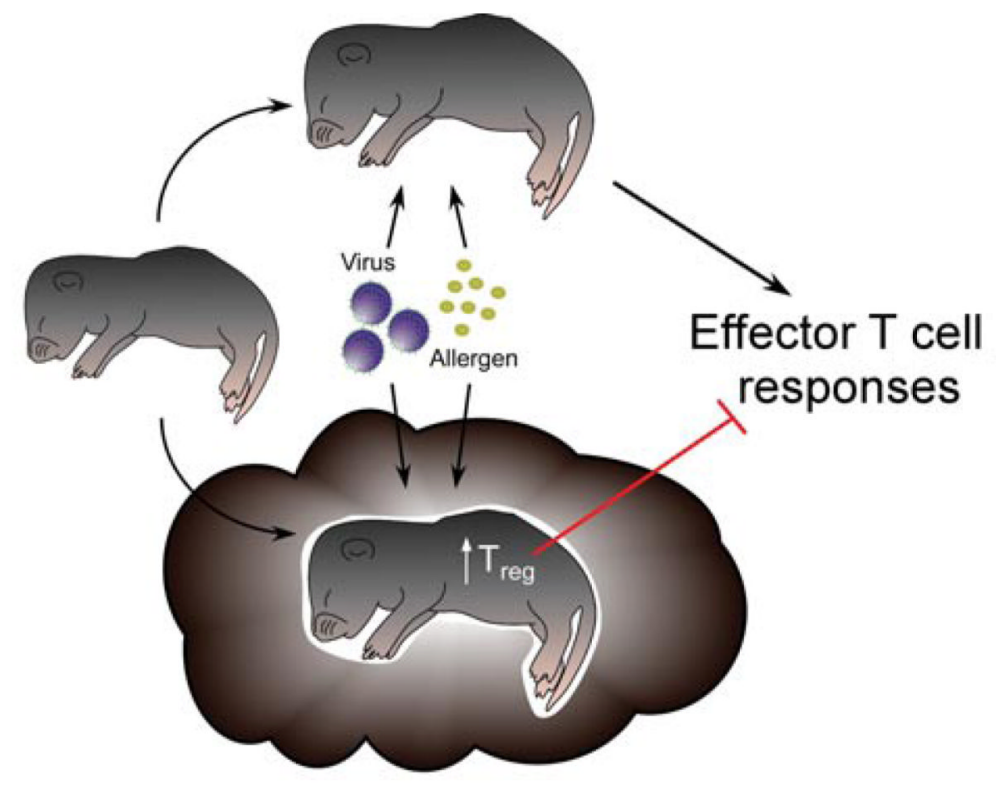

B

\section{PM Exposure}

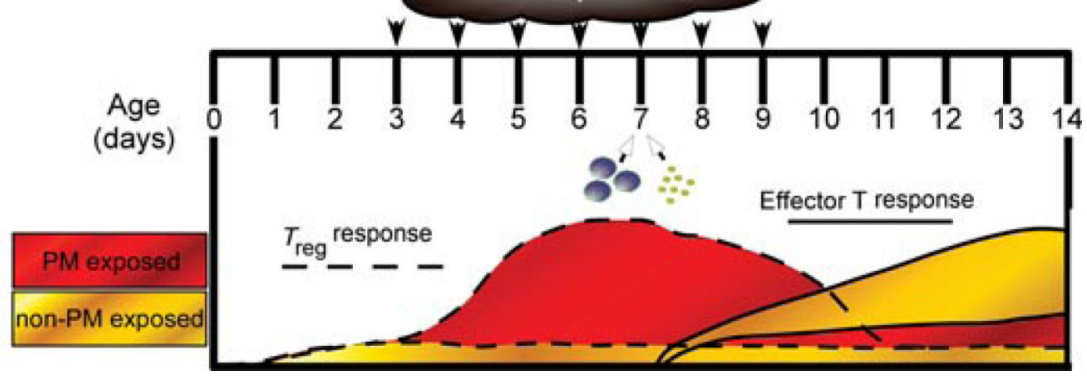

FIGURE 4.

Neonatal exposure to EPFR-containing PM causes an early Treg response that dampens subsequent effector $\mathrm{T}$ cell responses to antigen. (A) Descriptive overview. (B) Responses observed in our lab using our neonatal PM exposure model. With exposure beginning on day 3 of age, we see an increase in the amount of Tregs present in the lung that peaks around the fifth day of exposure. When the lung is given an additional insult at this time (e.g., allergen, influenza), effector $\mathrm{T}$ cell responses are dampened compared to nonexposed controls given the same challenge. 

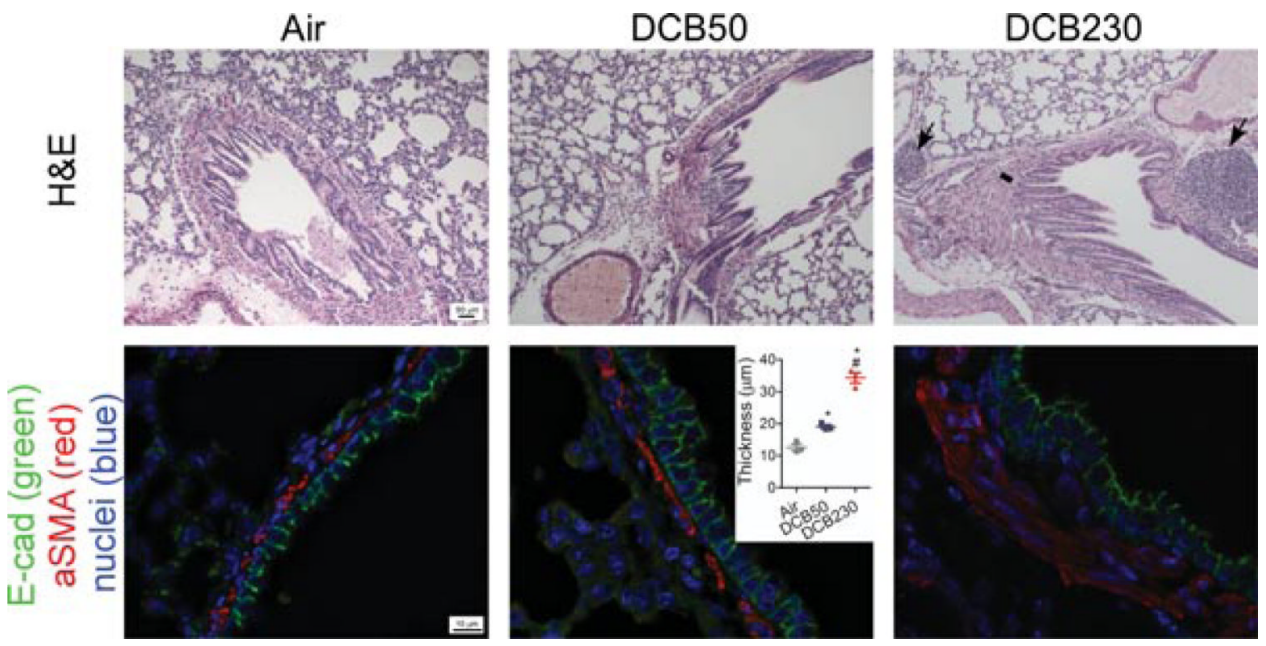

FIGURE 5.

Neonatal acute exposure to $\mathrm{EPFR}_{0.2}$ causes airway remodeling. (Top panel) Light micrographs of terminal bronchioles from 15-day old rat lungs exposed to control air, nonEPFR $_{0.2}$ (DCB50), or EPFR 0.2 (DCB230). Black arrows denote significant bronchiolar associated lymphoid tissue (BALT), and black line denotes significant increases in smooth muscle mass surrounding bronchiole. (Bottom panel) Micrographs of lung sections stained by immunohistochemistry for E-cadherin (green), $a$-smooth muscle actin (red), and cell nuclei (blue) with quantitative assessment of smooth muscle layer (inset). Figure adapted from Balakrishna et al. [70]. BioMed Central. 